\title{
Occupational Plans of Malaysian Educationally At-Risk Secondary School Students
}

\begin{abstract}
The study was conducted to determine the occupational plans of students who are educationally at-risk. About 11,400 students were involved in the study. About $49 \%$ of the respondents are male students and $51 \%$ are female students. The findings show that some of the students were not realistic in making occupational plans. Some of the occupations of their choices require college degrees or professional qualification. They may have problem in attaining those occupations because the majority of them are academically weak. Their grades in Mathematics and sciences were mostly D's. The study also shows that about $75 \%$ of the respondents are enrolled in elective vocational subjects while $25 \%$ of them are in MPV subjects. The elective vocational subjects are academic in nature as compared to MPV subjects. It would be better for human capital development purposes if educationally at-risk students are trained in skill development immediately after finishing their PMR examination. Thus, all secondary school in the country should offer the MPV subjects to cater for the academic needs of the educationally at-risk students. Without such an action we will be wasting our human capital. School counselors should also play a bigger role in guiding students towards the development of their potentials as future workers. The country needs skill workers to propel our economy in the future.
\end{abstract}

Keyword: At-risk Students, Occupational Choices 